FILOZOFIA

Roč. 75, 2020, č. 2

DOI: https://doi.org/10.31577/filozofia.2020.75.2.2

\title{
MOŽNOSTI REKONŠTRUKCIE, ANALÝZY A HODNOTENIA ARGUMENTOV ${ }^{1}$
}

LUKÁŠ BIELIK, Katedra logiky a metodológie vied, Filozofická fakulta Univerzity Komenského v Bratislave, Bratislava, SR

BIELIK, L.: Alternative Options for Reconstructing, Analyzing and Evaluating Arguments

FILOZOFIA, 75, 2020, No 2, pp. $91-108$

\begin{abstract}
Arguments formulated in a natural or scientific language usually allow for various different reconstructions. Alternative reconstructions may pertain to different approaches to inference and argumentation (such as classical predicate logic, Bayesian epistemology and many others). However, how are we to select one from among various available reconstructions? The paper provides an analysis of three different reconstructions of a particular argument and discusses their pros and cons with respect to several logical and extra-logical properties. Moreover, the three potential selection principles are considered. It is argued that they work adequately only when subjected to a specific aim of the context of argument-reconstruction.
\end{abstract}

Keywords: Argument - Argument-evaluation - Argument-reconstruction - Plurality of reconstructions - Selection principles

\section{1. Úvod}

Argumentácia, a vôbec používanie argumentov na viaceré kognitívne a komunikačné účely sú javy, ktoré zahŕňajú ako logické tak aj metodologické a pragmatické parametre. ${ }^{2}$ Ak chceme niektoré prvky tohto komplexu rekonštruovat', analyzovat' a hodnotit', nezaobídeme sa bez použitia určitých konceptuálnych (resp. analytických) metód (pozri napríklad Bielik 2019a, 3. kap.; a tiež Zouhar, Bielik, Kosterec

\footnotetext{
${ }^{1}$ Ďakujem obom anonymným recenzentom časopisu za konštruktívne pripomienky a spätnú väzbu $\mathrm{k}$ pôvodnej verzii state.

${ }^{2} \mathrm{~K}$ logickým vlastnostiam argumentov možno zaradit' napríklad logickú platnost', respektíve neplatnost', modality premís či záveru a pod. Spomedzi metodologických vlastností možno zmienit’ pravdivostnú hodnotu premís, respektíve záveru, ako aj charakterizácie, ktoré súvisia s tým, či daný argument plní funkciu zdôvodnenia, vysvetlenia, predikcie a pod. (Ked’že niektoré epistemické vlastnosti sú metodologicky relevantné a pravdivost' je takouto vlastnost'ou, chápeme ju ako metodologickú vlastnost'.) Napokon pragmatickými vlastnost’ami argumentu rozumieme napríklad jeho presvedčivost', ale aj d’alšie vlastnosti, ktoré súvisia s jeho výskytom v konkrétnom kontexte komunikácie.
} 
2017). Dôležité miesto v tomto procese majú metódy abstrakcie, idealizácie, ale aj postupy zahŕňajúce parafrázovanie či modifikáciu a dopíňanie pôvodných formulácií. ${ }^{3}$ Uvedené postupy majú za ciel' sprehl'adnit' jednak logickú štruktúru predmetného argumentu, jednak tiež d'alšie mimologické - predovšetkým metodologické a pragmatické - vlastnosti, ktoré vo výsledku ovplyvňujú celkové ohodnotenie analyzovaného argumentu.

Ukazuje sa však, že proces rekonštrukcie, analýzy a ohodnotenia argumentov vonkoncom nie je taký priamočiary a jednoznačný, ako sa na prvý pohl'ad môže javit'. Výber teoretických rámcov a nástrojov, prostredníctvom ktorých možno uskutočnit' transformáciu a analýzu pôvodného argumentu, je bohatý. ${ }^{4}$ Podobne existujú viaceré alternatívne kritériá, prostredníctvom ktorých možno ohodnotit' jednotlivé zložky argumentu i silu argumentu ako takého. Nemusí však byt' zrejmé, ktorú prípadnú rekonštrukciu (a teda aj prípadnú formalizáciu či schematickú reprezentáciu) prijat' ako adekvátnu či lepšiu ako ostatné alternatívne rekonštrukcie. A teda nemusí byt' jasné ani to, na základe ktorých (neekvivalentných) kritérií ohodnotit’ príslušný argument.

V tejto práci zvážim niektoré interpretačné princípy, ktoré by mohli plnit' rolu hl'adaných kritérií selekcie, aplikovatel'ných na rôzne alternatívne, respektíve konkurenčné rekonštrukcie argumentov. Myšlienkový postup článku bude nasledovný. V druhej časti najskôr objasním, v akom zmysle budem používat' spojenie rekonštrukcia argumentov. Odlišim v nej dve základné fázy rekonštrukcie argumentov a ukážem, že aspoň v niektorých prípadoch prvá fáza rekonštrukcie závisí od pojmového aparátu, ktorý je súčast’ou druhej fázy rekonštrukcie. V tretej časti sa pozriem na príklad argumentu (úsudku), ktorý možno rekonštruovat', analyzovat' a potom hodnotit' prostredníctvom odlišných teoretických a formálnych nástrojov neekvivalentným spôsobom. Ukáže sa, že slabé i silné stránky jednotlivých rekonštrukcií sú odlišné, a preto výber jednej z nich ako tej najlepšej, respektíve optimálnej sa nezaobíde bez určitého princípu selekcie, ktorý však nie je priamo súčastou teoretického rámca, $\mathrm{v}$ ktorom daná rekonštrukcia prebieha. Napokon $\mathrm{v}$ štvrtej časti podrobím analýze niekol'ko potenciálnych princípov selekcie a poukážem na ich dôsledky vo vzt’ahu k analýze argumentácie, respektíve používania argumentov vo všeobecnosti.

\footnotetext{
${ }^{3}$ Rozdiel medzi abstrakciou a idealizáciou osvetl'uje napríklad Jones (2005). V našom regióne sa obom metódam systematicky venuje Halas (2016); pozri tiež Bielik (2019a, s. 90 - 92). Osobitému využitiu oboch metód pri analýze argumentov sa venuje Halas (2019). Výborný úvod do problematiky parafrázovania a príbuzných úprav v súvislosti s rekonštrukciou argumentov predstavuje Picha (2014).

${ }^{4}$ Pojem teoretického rámca používam vo význame špecifikovanom v práci Bielik (2019b). Hlavné prístupy teórie argumentácie, ktoré možno využit' pri rekonštrukcii, analýze a hodnotení argumentov, možno nájst' v práci van Eemeren a kol. (2014). Niektoré d'alšie prístupy diskutuje publikácia Kyburg, Teng (2001).
} 


\section{Rekonštrukcia argumentov a jej fázy}

Rekonštrukcia argumentu predstavuje komplexnú činnost', ktorej výsledok závisí od viacerých logických i mimologických faktorov. Ak pristupujeme k určitej rekonštrukcii argumentu, znamená to, že sme určitý argument v danom komunikačnom kontexte už identifikovali - teda našli sme aspoň jeden taký výrok (tvrdenie), ktorý zastupuje tézu argumentu, a aspoň jeden d’alší výrok, ktorý reprezentuje dôvod na prijatie tejto tézy. ${ }^{5}$ Rekonštrukcia daného argumentu v jazyku, $\mathrm{v}$ ktorom bol pôvodne sformulovaný (teda zväčša v prirodzenom jazyku) môže pritom využívat' parafrázovanie, idealizáciu, abstrahovanie či vhodnú sémanticko-syntaktickú modifikáciu. Napríklad tézu i dôvod (dôvody) jej prijatia možno preformulovat' do podoby, ktorá niektoré výrazy pôvodnej formulácie nahrádza ich sémanticky kompaktnejšími alebo presnejšími alternatívami, prípadne niektoré nepodstatné výrazy vypúšta a iné - tie, ktoré reprezentujú určité zamlčané predpoklady daného komunikačného alebo kognitívneho kontextu -, zase explicitne dopíňa. Rekonštrukcia už pritom zahíňa aj preskupenie pôvodných prvkov argumentu do postupnosti, ktorá reprezentuje niektoré z pôvodných formulácií ako premisy (teda pôvodné dôvody na prijatie tézy) a určitú inú zložku reprezentuje ako záver (teda tézu) argumentu.

Sama rekonštrukcia argumentu však môže obsahovat' dve základné fázy: Prvá spočíva v transformácii pôvodného (neupraveného) argumentu, ktorý je formulovaný $\mathrm{v}$ (prirodzenom alebo odbornom) jazyku L do upravenej podoby argumentu, ktorý je opät' vyjadrený v tom istom jazyku L. Druhá fáza vychádza z výsledku prvej fázy, a teda zahŕňa transformáciu už upraveného argumentu (v jazyku L) do formálneho alebo poloformálneho (t. j. schematického) zápisu, ktorý je súčast'ou iného jazyka L* nejakého teoretického rámca, slúžiaceho na analýzu argumentov. Tieto dve fázy si teraz bližšie predstavíme.

Povedali sme už, že prvá fáza predstavuje proces, v ktorom sa z pôvodnej (hovorenej alebo napísanej) podoby argumentu, ktorý bol formulovaný prostredníctvom jazyka L, vyextrahuje upravená podoba argumentu, pričom aj takto upravený argument je vyjadrený jazykovými prostriedkami toho istého jazyka L. Jazykom L môže byt' v tomto prípade prirodzený jazyk, ale aj odborný či vedecký jazyk. Napríklad, majme pred sebou nasledovný textový fragment:

\section{Pôvodný argument (PA)}

Peter si kúpil novú Škodu Rapid. Včera sme boli s manželkou a det’mi v meste na pizzu a zazreli sme ho, ked’ nás obiehal.

\footnotetext{
${ }^{5}$ Naše vymedzenie argumentu predpokladá, že množina premís je vždy neprázdna, čo síce nekorešponduje s vymedzením argumentu v logike (kde sa pripúšta aj prázdna množina premís), no ide o prax bežnú $\mathrm{v}$ teórii argumentácie.
} 
Hoci je možné tento textový útvar interpretovat' aj ako opis dvoch časovo následných udalostí, je prípustné, aby sme ho (vzhl'adom na určitý kontext) interpretovali aj ako argument. V takom prípade prvú vetu stotožníme s výrokom, ktorý vyjadruje určitú tézu, zatial' čo druhú vetu rekonštruujeme ako dôvod, ktorý je uvedený $\mathrm{v}$ prospech prijatia danej tézy (prípadne ako vysvetlenie, prečo zastávame danú tézu). Prvá fáza rekonštrukcie tak môže pôvodný argument transformovat' do modifikovanej podoby napríklad takto:

\section{Rekonštrukcia argumentu (RA)}

(P) Videli sme Petra šoférovat' novú Škodu Rapid.

(Z) Teda Peter si kúpil novú Škodu Rapid.

V tejto rekonštrukcii nevystupujú všetky výrazy pôvodnej formulácie a niektoré termíny boli nahradené inými, významovo ekvivalentnými alebo blízkymi termínmi. ${ }^{6}$ Navyše v tejto rekonštrukcii je explicitne zachytené, ktorý výrok zastupuje premisu a ktorý záver daného argumentu; poslúžili nám k tomu symboly „(P)“ a „,(Z)“.

Uvedená rekonštrukcia nie je, samozrejme, jediná možná. Alternatívna rekonštrukcia by mohla vziat' do úvahy d'alšie informácie, ktoré explicitne nevystupujú $\mathrm{v}$ danom texte, a mohla by ich vyjadrit' prostredníctvom dodatočnej, takzvanej zamlčanej premisy. Podoba tejto alternatívnej rekonštrukcie by mohla vyzerat’ takto:

\section{Rekonštrukcia argumentu * $\left(\mathbf{R A}^{*}\right)$}

(P1) Ak sme Petra videli šoférovat' novú Škodu Rapid, tak (to znamená, že) Peter si kúpil novú Škodu Rapid.

(P2) Videli sme Petra šoférovat' novú Škodu Rapid.

(Z) Peter si kúpil novú Škodu Rapid.

Táto rekonštrukcia pôvodného argumentu sa od tej predchádzajúcej líši (okrem explicitného oddelenia premís od záveru pomocou horizontálnej čiary) v tom, že pracuje s pojmom zamlčanej premisy, respektíve zamlčaného predpokladu vyjadrujúceho informáciu, ktorá mohla (no nemusela) byt' súčast’ou predpokladov, s ktorými autor pôvodného argumentu pri odvodení záveru pracoval či o ktoré sa nepriamo opieral. Môže však íst' aj o informáciu, s ktorou autor daného textu (alebo argumentu) vôbec nepracoval a ktorú do rekonštrukcie vložila až osoba analyzujúca daný argument. Odpoved’

\footnotetext{
${ }^{6}$ Parafrázovanie či terminologická modifikácia by mali byt' pritom podriadené podmienke zachovania pravdivostnej hodnoty pôvodnej formulácie. Vo viacerých prípadoch do tohto procesu vstupujú rôzne pragmatické faktory, ktoré sú prítomné či už v kontexte výskytu pôvodného argumentu, alebo $\mathrm{v}$ kontexte jeho rekonštrukcie.
} 
na otázku, či zamlčaná premisa vyjadruje skrytý predpoklad usudzovania autora argumentu alebo autora jeho rekonštrukcie, sa zrejme líši prípad od prípadu. A možno tiež pripustit' situácie, ked' ani autor argumentu ani autor rekonštrukcie nevedia priamo povedat', či práve daná zamlčaná premisa patrí k predpokladom, o ktoré sa ich argument (alebo odvodenie záveru) opieral(-o). Napokon autor rekonštrukcie argumentu môže rekonštruovat' daný argument viacerými konkurenčnými spôsobmi (ako sme to urobili aj my vyššie a ako to ešte uvidíme v nasledujúcej časti), pričom nemusí preferovat' žiadnu z alternatívnych rekonštrukcií, alebo môže preferovat' niektoré na úkor iných a pod.

Vidíme teda, že už prvá fáza rekonštrukcie pripúšt’a viaceré možnosti neekvivalentých transformácií pôvodného argumentu. A hoci to nemusí platit’ bez výnimky, rekonštrukcia argumentu sa zvyčajne prvou fázou nekončí. Výsledok rekonštrukcie v prvej fáze sa stáva vstupom pre druhú fázu rekonštrukcie. Tá, ako sme uviedli, znamená transformáciu už rekonštruovaného argumentu z jedného jazyka $L$ do iného jazyka $L^{*}$, pričom $L^{*}$ je štandardne jazyk určitej teórie inferencie alebo teórie argumentácie, teda jazyk istého teoretického rámca. Napríklad rekonštrukciu argumentu (RA*) možno v jazyku výrokovej logiky, ktorá je jednou z teórií inferencie (a teda potenciálnym teoretickým rámcom), rekonštruovat' do podoby logicky platného úsudku formy Modus ponens:

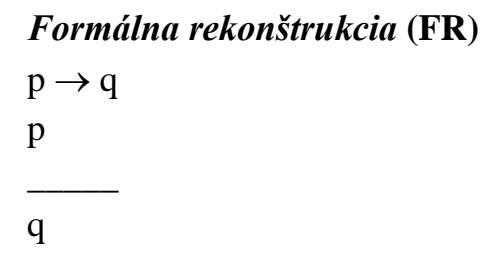

kde „p“ zastupuje výrok „Petra sme videli šoférovat’ novú Škodu Rapid“, „q“ zase výrok „Peter si kúpil novú Škodu Rapid“ a symbol „ $\rightarrow$ “ reprezentuje materiálnu implikáciu, ktorou možno nahradit' (niektoré) výskyty spojky „ak..., tak...“.

Iná, alternatívna formálna rekonštrukcia tej istej neformálnej rekonštrukcie (RA*) by mohla vyzerat' takto:

\section{Formálna rekonštrukcia * $\left(\mathrm{FR}^{*}\right)$}

$$
\operatorname{Pr}(\mathrm{Z} \mid \mathrm{P} 1 \wedge \mathrm{P} 2)=1
$$

kde „Pr“ reprezentuje funkciu (podmienenej) pravdepodobnosti, definovanú na konečnej množine $L_{p}$ výrokov spíňajúcu (napríklad) Kolmogorove axiómy teórie pravdepodobnosti, a kde „Z“, resp. „P1“ a „P2“ zastupujú záver a premisy argumentu 
(RA*), pričom celý zápis čítame: „Pravdepodobnost', že je pravdivý záver Z za predpokladu, že sú pravdivé premisy P1 a P2, sa rovná 1."7 Vertikálna čiara ,"“ v tejto formalizácii reprezentuje oddelenie záveru od premís pomocou funkcie podmienenej pravdepodobnosti.

(Klasická) výroková logika i teória pravdepodobnosti (definovaná na konečnej množine elementárnych výrokov nejakého jazyka $L_{P}$ ) tak predstavujú dva potenciálne teoretické rámce, $\mathrm{v}$ rámci ktorých možno realizovat’ druhú fázu rekonštrukcie určitého argumentu. K niektorým zaujímavým dôsledkom, ktoré z existencie viacerých formálnych i poloformálnych teoretických rámcov vo všeobecnosti vyplývajú, sa dostaneme $\mathrm{v}$ tretej a štvrtej časti tohto článku. Teraz sa však ešte $\mathrm{v}$ krátkosti venujme vzt’ahu medzi prvou a druhou fázou rekonštrukcie.

Po prvé, zdá sa, že nič nebráni tomu, aby niekto, kto chce rekonštruovat' pôvodnú podobu argumentu, uskutočnil len prvú, neformálnu fázu rekonštrukcie. Existujú viaceré komunikačné situácie, v ktorých je postačujúce, aby si diskutéri vyjasnili, čo je téza (alebo čo sú tézy) a čo sú predpoklady uvádzané ako dôvody v jej prospech (alebo neprospech). V takom prípade môže postačovat', ked' sa pôvodná podoba argumentu pretransformuje do takej modifikovanej podoby, v ktorej sa odhliada od nepodstatných syntakticko-sémantických prvkov, a naopak, dopíňajú sa tie prvky, ktoré sú podstatné pre zachytenie štruktúry daného argumentu.

Po druhé, logici, teoretici argumentácie a d’alší, ktorí analyzujú argumenty, niekedy pristupujú priamo $\mathrm{k}$ transformácii pôvodnej podoby argumentu, vyjadrenej v jazyku L, do formálnej alebo poloformálnej rekonštrukcie, ktorej symbolický aparát (jazyk $L^{*}$ ) poskytuje príslušný teoretický rámec, v ktorom rekonštrukcia prebieha. Inak povedané, rekonštrukcia argumentu môže prebiehat' aj spôsobom, ked' sa pôvodný argument (napríklad (PA) vyššie) pretransformuje priamo na formalizovaný argument (napríklad (FR)), pričom medzikrok rekonštrukcie - teda prechod od prvej fázy do druhej fázy - sa preskočí. Neraz je tento spôsob realizácie rekonštrukcie daný tým, že symbolický aparát príslušného teoretického rámca už vopred určuje, ktoré syntaktické a sémantické zložky pôvodného argumentu v ňom možno adekvátne reprezentovat' a ktoré nie. To znamená, že keby teoretickým rámcom bola klasická výroková logika, tak rekonštrukcia pôvodného argumentu si bude všímat' len tie prvky pôvodného argumentu, ktoré možno vyjadrit' ako jednoduché alebo zložené výroky, ktorých štruktúru tvoria logické spojky (negácia, konjunkcia, disjunkcia, materiálna implikácia a materiálna ekvivalencia). Ak však za teoretický rámec vezmeme klasickú

\footnotetext{
${ }^{7}$ Pôvodná verzia Kolmogorovej axiomatizácie teórie pravdepodobnosti bola formulovaná na algebre množín (pozri Kolmogorov 1950). Teoretici induktívnej inferencie však preferujú definovanie pravdepodobnostnej funkcie na prvkoch (konečnej) množiny určitého vhodného jazyka. Pozri napríklad Carnap (1962/1950), a tiež Roeper, Leblanc (1999).
} 
predikátovú logiku (prvého rádu), tak rekonštrukcia bude schopná zachytit' a vyjadrit' aj vnútornú štruktúru jednoduchých (a teda aj zložených) výrokov, a tiež výrazy zastupujúce kvantifikáciu (teda výrazy ako „každá“, „,niektoré“, „žiaden““ a pod.).

Napokon v prípadoch, ked’ sa rekonštrukcia argumentu realizuje prostredníctvom oboch fáz, by sa mohlo javit', že ked’že vstupom druhej fázy rekonštrukcie je výstup (výsledok) prvej fázy rekonštrukcie, tak prvá fáza rekonštrukcie ( $v$ istom zmysle) determinuje podobu druhej fázy rekonštrukcie. Avšak vplyv konkrétneho teoretického rámca, s ktorým autor rekonštrukcie pristupuje $\mathrm{k}$ analýze pôvodného argumentu, môže určovat' aj tie syntaktické a sémantické prvky pôvodnej formulácie, ktoré sa vyberú, respektíve modifikujú do podoby neformálnej rekonštrukcie v prvej fáze. Existujú teda prípady, ked' teoretický rámec explicitne prítomný v druhej fáze rekonštrukcie predurčuje (do značnej miery) neformálnu rekonštrukciu prvej fázy. Napríklad ak pôvodný argument (PA) chce analyzovat' logik, ktorý preferuje deduktívne teoretické rámce (napríklad výrokovú alebo predikátovú logiku) pred nededuktívnymi rámcami, táto jeho teoretická (pojmová) výbava môže byt' dôvodom, pre ktorý uprednostní neformálnu rekonštrukciu (RA*) pred rekonštrukciou (RA), pretože (RA*) reprezentuje (PA) ako deduktívne platný argument, zatial' čo (RA) reprezentuje (PA) ako deduktívne neplatný argument. Formálna rekonštrukcia tak aspoň v niektorých prípadoch determinuje podobu alebo výber (konkrétnej) neformálnej rekonštrukcie.

\section{Pluralita rekonštrukcií}

V tejto časti sa pozrieme na možnosti rekonštrukcie jedného konkrétneho argumentu, ktorý možno s prihliadnutím na odlišné teoretické rámce či pojmový aparát rekonštruovat' (minimálne) troma odlišnými spôsobmi: a) ako chybný argument známy pod názvom argumentum ad ignorantiam; b) ako logicky platný argument; c) ako pravdepodobnostný argument. Hoci sa v tejto časti obmedzujeme na analýzu jedného argumentu a jeho troch možných rekonštrukcií, výsledky, ku ktorým naša analýza dospeje, možno zovšeobecnit' aj na prípady iných argumentov alebo ich rekonštrukcí́.

Predstavme si, že máme pred sebou nasledujúci textový fragment, ktorý obsahuje argument:

(A) Liečivo $X$ nemá žiadne nežiaduce vedl’ajšie účinky. Testy na laboratórnych potkanoch totiž nepreukázali žiadne nežiaduce účinky.

Argument (A) možno v prvej i druhej fáze rekonštruovat' viacerými možnými spôsobmi. Tie, ktoré predstavíme nižšie, nie sú jediné prípustné. Našu pozornost' tu však obmedzíme na tri základné prístupy, ktorých výsledkom sú tri odlišné druhy rekonštrukcie (a teda aj tri odlišné rekonštrukcie) pôvodného argumentu. 
Prvý spôsob, ktorým možno v prvej fáze rekonštruovat' argument (A), môže mat' takúto podobu:

\section{(RA1)}

(P) Neexistuje evidencia, ktorá by ukázala, že liečivo X má nežiaduce účinky.

(Z) Teda liečivo $\mathrm{X}$ nemá nežiaduce účinky.

Keby sme si za teoretický rámec druhej fázy rekonštrukcie argumentu (A) zvolili napríklad klasickú výrokovú logiku, tak rekonštruovaný argument (RA1) by sme následne $\mathrm{v}$ druhej fáze mohli pretransformovat' na argument formy:

\section{(FR1)}

$\mathrm{p}$

q

kde „„“ zastupuje výrok „Neexistuje evidencia, ktorá by ukázala, že liečivo X má nežiaduce účinky“" a „q“ zase výrok „Teda liečivo X nemá nežiaduce účinky“, pričom je zjavné, že q nie je logickým dôsledkom p. Alternatívne by sme argument (RA1) z prvej fázy rekonštrukcie mohli preformulovat' do poloformálnej podoby, ktorá by obsahovala výrokové premenné, negáciu a operátor „Nie je známe, že“ alebo „Neexistuje evidencia, že“:

\section{(FR1*)}

Nie je známe, že (resp. neexistuje evidencia, že) r.

$$
\neg \mathrm{r}
$$

kde „„“ zastupuje výrok „Liečivo X má nežiaduce účinky“. Argumenty s logickou formou reprezentovanou schémou (FR1*) sú (najmä) v učebniciach logiky i v niektorých prácach z teórie argumentácie známe ako chyba argumentum ad ignorantiam, teda argument, v ktorom $\mathrm{z}$ absencie evidencie (chybne) usudzujeme na evidenciu absencie. ${ }^{8}$ Dlho pretrvával, a vlastne dodnes pretrváva názor, že argumenty podobné argumentu (A) sú typickou chybou argumentácie. A tak rekonštrukcia argumentu (A) prostredníctvom (FR1*) pôvodný argument reprezentuje - a následne umožňuje aj jeho hodnotenie - ako prípad argumentačnej chyby argumentum ad ignorantiam.

${ }^{8}$ Pozri napríklad Bonevac $(1999,114$ - 115), ale aj novšie vydania známej učebnice logiky Copi, Cohen, McMahon (2014, $130-133)$. 
Avšak argument (A) možno rekonštruovat' (v prvej i druhej fáze) aj iným spôsobom. Ide o rekonštrukciu, ktorú v systematickej podobe predstavuje Douglas Walton v práci Arguments from Ignorance (pozri Walton 1996). ${ }^{9}$ Ak totiž k pôvodnému textovému podkladu argumentu (A) doplníme aj potenciálny zamlčaný predpoklad, výsledok neformálnej rekonštrukcie argumentu (A) môže reprezentovat' nasledujúci argument:

\section{(RA2)}

(P1) Ak má liečivo $X$ nežiaduce vedlajšie účinky, tak laboratórne testy $t_{1}, \ldots, t_{n}$ odhalia, že X má nežiaduce účinky.

(P2) Ani jeden $\mathrm{z}$ laboratórnych testov $\mathrm{t}_{1}, \ldots, \mathrm{t}_{\mathrm{n}}$ neodhalil, že $\mathrm{X}$ má nežiaduce účinky.

(Z) Liečivo X nemá nežiaduce vedlajšie účinky.

Alternatívnu, avšak vel'mi príbuznú rekonštrukciu argumentu (A) by sme dostali, ak by sme spojenie ,laboratórne testy $t_{1}, \ldots, t_{n}$ odhalia“ $z$ rekonštrukcie (RA2) nahradili spojením „existuje evidencia“:

\section{(RA2*)}

(P1) Ak má liečivo X nežiaduce vedlajšie účinky, tak existuje evidencia, že X má nežiaduce účinky.

(P2) Neexistuje evidencia, že X má nežiaduce účinky.

(Z) Liečivo X nemá nežiaduce vedlajšie účinky.

Rekonštrukcie (RA2) a (RA2*) možno interpretovat' z pohl'adu výrokovej logiky ako ekvivalentné, pretože obe možno s určitým zjednodušením (zahrnujúcim abstrahovanie od odlišných časov príslušných slovies) v druhej fáze rekonštrukcie pretransformovat' na argument formy:

(FR2)

$$
\begin{aligned}
& \mathrm{p} \rightarrow \mathrm{q} \\
& \neg \mathrm{q} \\
& \neg \mathrm{p}
\end{aligned}
$$

\footnotetext{
${ }^{9}$ Walton sa argumentom odvolávajúcim sa na absenciu evidence venoval už v práci Walton (1992) Na druhej strane jeho novšia práca (pozri Walton, Reed, Macagno 2008) obsahuje modifikovanú verziu rekonštrukcie tohto typu argumentov, ktorá sa od tu uvedenej líši.
} 
kde „p“ zastupuje výrok „Liečivo X má nežiaduce vedlajšie účinky“ a „,“ zasa výrok „Existuje evidencia (respektíve laboratórne testy $t_{1}, \ldots, t_{n}$ odhalia), že X má nežiaduce účinky“. Ide o argument (presnejšie, schému argumentu), ktorého výrokovo-logická forma zodpovedá inferenčnému pravidlu Modus tollens, ktoré je logicky platné. To znamená, že ak budeme mat' úsudok s touto logickou formou a pôjde zároveň o prípad, že obidve jeho premisy budú pravdivé, záver argumentu bude musiet' byt' pravdivý.

Napokon sa pozrime na tretí možný spôsob rekonštrukcie argumentu (A), ktorý predstavujú Oaksford, Hahn (2004) a Hahn, Oaksford (2006). Ide o prístup vychádzajúci z bayesiánskej teórie potvrdenia, respektíve z bayesiánskej teórie argumentácie. Oaksford a Hahn sa zhodujú v tom, že niektoré argumenty, ktoré bývajú klasifikované ako argumentum ad ignorantiam, sú neakceptovatel'né. Napríklad argument, ktorého záver tvrdí, že duchovia existujú, pričom ako dôvod v prospech záveru uvádza premisu, že nik doteraz nedokázal, že duchovia neexistujú, sa ukazuje ako neakceptovatel'ný. Oaksford a Hahn však hovoria: „,T] vrdíme, že to nie je kvôli tomu, že by štruktúra argumentu, ktorá mu prislúcha, bola chybná, ako to pohl’ad logikov tradične predpokladal. Argument je z hl'adiska štruktúry úplne prijatel'ný, no jeho slabinou je skôr jeho konkrétny obsah“ (Oaksford, Hahn 2004, 75). Obaja autori pritom na ohodnotenie obsahu premís a záveru používajú aparát bayesiánskej epistemológie, ku ktorému patrí nielen využívanie Bayesovej teorémy (ako hlavného inferenčného pravidla), ale aj interpretácia pravdepodobností (ktoré v danej teoréme vystupujú) ako subjektívnych stupňov presvedčenia (konkrétnych či ideálnych aktérov.)

Bez toho, aby sme zašli do detailov ich prístupu, predstavme si aspoň základný aparát, prostredníctvom ktorého možno rekonštruovat' argument (A) ako pravdepodobnostný argument. Bayesiánska rekonštrukcia argumentu (A) pritom umožňuje odlišným aktérom vykonat' odlišné rekonštrukcie, a to v závislosti od konkrétnej hodnoty ich východiskových pravdepodobností, respektíve pravdepodobností, ktoré vstupujú do Bayesovej teorémy (pozri nižšie). V tom, čo bude nasledovat', však od konkrétnych pravdepodobnostných hodnôt odhliadneme a celú rekonštrukciu priblížime v zovšeobecnenej podobe, ktorá síce vychádza z práce Oaksford, Hahn (2004), a Hahn, Oaksford (2006), no v niektorých aspektoch ju modifikuje (pozri tiež Stephens 2011).

V prvom kroku sa pozrime na to, ako by mohla vyzerat' neformálna rekonšstrukcia argumentu (A) tak, aby sme zachytili jeho možnú pravdepodobnostnú interpretáciu. Jednou z možností by bolo rekonštruovanie argumentu (A) v nasledujúcej podobe: 


\section{(RA3)}

Pravdepodobnost', že liečivo X nemá nežiaduce účinky za predpokladu, že neexistuje evidencia, že X má nežiaduce účinky, je vyššia ako (východisková) pravdepodobnost', že liečivo nemá nežiaduce účinky.

Oaksford a Hahn neformulujú explicitne rekonštrukciu (RA3), no ich prístup je zlučitel'ný s navrhovanou (neformálnou) rekonštrukciou.

Skôr ako pristúpime $\mathrm{k}$ druhej fáze pravdepodobnostnej rekonštrukcie argumentu (A), treba zaviest' a stručne okomentovat' fragment symbolického jazyk L*, o ktorý sa uvedená bayesiánska rekonštrukcia opiera.

Nech „H“ reprezentuje určitú hypotézu, v našom prípade to bude hypotéza „Liečivo X má nežiaduce účinky.“ Podobne tak „ $\neg \mathrm{H}^{\prime \prime}$ bude zastupovat' negáciu hypotézy H, v našom prípade teda výrok „Liečivo X nemá nežiaduce účinky.“ D̃alej nech „E“ reprezentuje nejakú relevantnú evidenciu - v našom prípade ide o výrok „Existuje evidencia, že liečivo X má nežiaduce účinky“, a , $\neg E^{\prime \prime}$ nech reprezentuje negáciu pôvodného výroku, v našom prípade výrok „Neexistuje evidencia, že liečivo X má nežiaduce účinky“. Zápis „ $\operatorname{Pr}(\mathrm{H}) “$ potom reprezentuje východiskovú pravdepodobnost' hypotézy $\mathrm{H}$, ktorou môže byt' teoreticky l'ubovol'né reálne číslo $\mathrm{r} \in[0,1] ;, „ \operatorname{Pr}(\neg \mathrm{H})$ “ zase východiskovú pravdepodobnost' hypotézy $\neg \mathrm{H} . \operatorname{Pr}(\mathrm{H})$, resp. $\operatorname{Pr}(\neg \mathrm{H})$ vyjadrujú stupeň presvedčenia, že daná hypotéza je pravdivá, a to ešte predtým, než ju podrobíme testovaniu. Obe východiskové pravdepodobnosti tak reprezentujú prijatel'nost' príslušnej hypotézy, do ktorej sa môžu premietnut také skutočnosti ako to, či je daná hypotéza zlučitel'ná s doterajším stavom nášho poznania, či ide o ontologicky jednoduchú alebo zložitú hypotézu a pod.

Výrazy „Pr $\operatorname{Pr}(\neg \mathrm{E} \mid \neg \mathrm{H}) “$ a „,Pr $(\neg \mathrm{E} \mid \mathrm{H})$ “ zase zastupujú (v danom poradí) „pravdepodobnost', že je pravda non-E za predpokladu, že je pravda non-H“, respektíve „pravdepodobnost', že je pravda non-E za predpokladu, že je pravda $\mathrm{H}^{\text {“. }}$ K bližšej charakterizácii oboch výrazov sa ešte vrátime.

Napokon, Bayesovu teorému možno uviest' v niekol'kých (ekvivalentných) podobách, no na účely našej bayesiánskej rekonštrukcie argumentu (A) postačí, ak si zvolíme túto formu:

\section{(BT)}

$$
\operatorname{Pr}(\neg H \mid \neg E)=\frac{\operatorname{Pr}(\neg H) * \operatorname{Pr}(\neg E \mid \neg H)}{\operatorname{Pr}(\neg H) * \operatorname{Pr}(\neg E \mid H)+\operatorname{Pr}(H) * \operatorname{Pr}(\neg E \mid H)}
$$

Lavá strana (BT) predstavuje pravdepodobnost' $\neg \mathrm{H}$ za predpokladu, že je pravda $\neg$ E. Inak povedané, l'avá strana vyjadruje pravdepodobnost', že liečivo X je bezpečné 
za predpokladu, že neexistuje evidencia, ktorá by preukazovala nejaké jeho toxické účinky. Pravá strana (BT) zase poskytuje návod, ako sa k hodnote na l’avej strane dopracovat', ak máme k dispozícii potrebné pravdepodobnosti. Navyše ak k Bayesovej teoréme (BT) pripojíme aj bayesiánske kritérium potvrdenia (prispôsobené na negované formy hypotézy i evidencie):

(BP)

Hypotéza $\neg \mathrm{H}$ je potvrdená evidenciou $\neg$ E práve vtedy, ked'

$\operatorname{Pr}(\neg \mathrm{H} \mid \neg \mathrm{E})>\operatorname{Pr}(\neg \mathrm{H})^{10}$

môžeme rekonštruovat' argument (RA3) v druhej fáze takto:

\section{(FR3)}

$\operatorname{Pr}(\neg \mathrm{H} \mid \neg \mathrm{E})>\operatorname{Pr}(\neg \mathrm{H})$

Rekonštrukcia (FR3), Bayesova teoréma (BT), ako aj bayesiánske kritérium potvrdenia (BP) si vyžadujú komentár.

Predpokladajme, že výskumník chce testovat' hypotézu $\neg \mathrm{H}$, teda hypotézu, že liečivo X nemá nežiaduce účinky. Ak predpokladáme, že nemá $\mathrm{k}$ dispozícii také relevantné informácie, ktoré by ho viedli k preferovaniu hypotézy $\mathrm{H}$ pred hypotézou $\neg \mathrm{H}$, môže (v súlade s axiómami teórie pravdepodobnosti) stanovit', že $\operatorname{Pr}(\mathrm{H})=\operatorname{Pr}(\neg \mathrm{H})=1 / 2$. Toto priradenie pravdepodobností vyjadruje stupeň jeho rovnomerného rozdelenia pravdepodobnosti dvom navzájom sa vylučujúcim a logický priestor vyčerpávajúcim hypotézam. Čo však v našom prípade reprezentujú výrazy „, $\operatorname{Pr}(\neg \mathrm{E} \mid \neg \mathrm{H}) “$ “ a „ $\operatorname{Pr}(\neg \mathrm{E} \mid \mathrm{H})$ ““? Ten prvý vyjadruje pravdepodobnost', že testy nepreukážu toxické účinky liečiva $X$, ak nie je liečivo $X$ toxické. Táto pravdepodobnost' je zrejme vysoká, hoci zrejme nie je rovná 1 , ked’že do procesu testovania môžu vstúpit' faktory, ktoré v ojedinelých prípadoch môžu viest' k pozitívnemu výsledku testu, a to aj napriek tomu, že samo liečivo X je bezpečné. Druhý výraz zase vyjadruje pravdepodobnost', že testy nepreukážu toxické účinky liečiva $X$, aj ked' je liečivo $X$ toxické. Platí, že ak sú testy na toxicitu liečiva $X$ vysoko senzitívne (teda $\operatorname{Pr}(E \mid H)$ sa blíži k jednej), tak hodnota $\operatorname{Pr}(\neg \mathrm{E} \mid \mathrm{H})$ sa bude blížit' $\mathrm{k}$ nule.

Bayesova teoréma (BT) nám potom umožňuje vypočítat' hodnotu takzvanej následnej (podmienenej) pravdepodobnosti $\operatorname{Pr}(\neg \mathrm{H} \mid \neg \mathrm{E}$ ), teda pravdepodobnosti, že liečivo $\mathrm{X}$ nie je toxické, za predpokladu, že neexistuje evidencia o jeho toxicite. Ak navyše platí, že východisková pravdepodobnost' $\operatorname{Pr}(\neg \mathrm{H})=\mathrm{r}_{1}$ a $\operatorname{Pr}(\neg \mathrm{H} \mid \neg \mathrm{E})=\mathrm{r}_{2}$, pričom

10 Pozri napríklad Howson, Urbach (1993, 117 a d’alej). 
$\mathrm{r}_{2}>\mathrm{r}_{1}$ a $0<\mathrm{r}_{1}, \mathrm{r}_{2}<1$, tak v zmysle vyššie uvedeného bayesiánskeho kritéria potvrdenia (BP) platí, že negatívna evidencia $\neg$ E potvrdzuje hypotézu $\neg \mathrm{H}$ o absencii nežiaducich účinkov liečiva $X$.

Pôvodný argument (A) teda možno bayesiánskym spôsobom interpretovat' tak, že jeho autor predpokladá (v súlade s bayesiánskym kritériom potvrdenia), že negatívna evidencia zvyšuje pravdepodobnost' hypotézy o netoxicite daného liečiva v porovnaní s východiskovou pravdepodobnost'ou tejto hypotézy.

Samozrejme, predstavenie tohto tretieho prístupu je na účely tejto práce zjednodušené a schematické, navyše opomína niektoré jeho silné i slabé stránky. Čitatela preto odporúčame na práce (Oaksford, Hahn 2004, Hahn, Oaksford 2006 či Stephens 2011), ktoré sa bayesiánskej rekonštrukcii tohto typu argumentu venujú detailne.

To, čo naša analýza nateraz ukazuje, je fakt, že jeden a ten istý argument možno rekonštruovat' (a následne aj hodnotit') odlišnými, neekvivalentnými spôsobmi. Na niektoré dôsledky, ku ktorým tento relatívne triviálny fakt vedie, upozorníme v nasledujúcej časti.

\section{Porovnanie a selekcia rekonštrukcií}

Uvedené tri rekonštrukcie argumentu (A) majú zjavne svoje silné i slabé stránky. Pre zjednodušenie budem $\mathrm{v}$ tejto časti článku na prvú, druhú a tretiu rekonštrukciu postupne referovat' ako na R1, R2 a R3.

$\mathrm{V}$ prípade R1 možno povedat', že prechod od (A) $\mathrm{k}$ (RA1) a následne prechod od (RA1) k (FR1*) je viac-menej konzervatívny. Rekonštrukcia R1 pôvodného argumentu (A) sa tak len minimálne líši od svojho zdroja, a to ako v prípade reprezentácie nededuktívnej relácie medzi premisou a záverom, tak aj pokial' ide o reprezentáciu explicitného informačného obsahu premisy pôvodného argumentu. R1 nemení ani inferenčnú reláciu, ani informačný obsah (A). Keby sme mali v d'alšom kroku ohodnotit' aj premisu $(\mathrm{P})$ z prvej fázy rekonštrukcie (teda výrok „Neexistuje evidencia, ktorá by ukázala, že liečivo X má nežiaduce účinky“), dalo by sa povedat', že táto rekonštrukcia zachováva pravdivost' informačného obsahu pôvodného argumentu. Inak povedané, ak je premisa pôvodného argumentu (A) pravdivá, je pravdivý aj informačný obsah (vyjadrený premisou (P)) rekonštruovaného argumentu (RA1). R1 teda pomerne priamočiaro vyjadruje viaceré klúčové logické i mimologické vlastnosti argumentu (A). Na druhej strane R1 býva štandardne charakterizovaná ako chyba usudzovania známa pod názvom argumentum ad ignorantiam.

Rekonštrukcia R2 - teda prechod od (A) k (RA2), respektíve (RA2*), a prechod od (RA2), respektíve (RA2*) k (FR2) - sa od R1 líši vo viacerých ohl'adoch. Po prvé, $\mathrm{R} 2$ pridáva $\mathrm{k}$ explicitnému informačnému obsahu premisy pôvodného argumentu (A) aj d'alši predpoklad, ktorý i) mohol, no nemusel patrit' medzi predpoklady, ktoré autor 
argumentu (A) zastával; a ii) ktorého zaradenie medzi premisy rekonštruovaného argumentu mení charakter inferenčnej relácie. Kým totiž explicitný obsah premisy argumentu (A) nepostačoval na to, aby medzi premisou a záverom (A) bola relácia logického vyplývania, zaradenie premisy (P1) (teda výroku „Ak má liečivo X nežiaduce vedlajšie účinky, tak laboratórne testy $\mathrm{t}_{1}, \ldots, \mathrm{t}_{\mathrm{n}}$ odhalia, že $\mathrm{X}$ má nežiaduce účinky“) medzi premisy rekonštruovaného argumentu (RA2) zabezpečuje, že relácia medzi premisami a záverom (RA2) je reláciou logického vyplývania. R2 tak mení jednak informačný obsah, jednak druh inferenčnej relácie pôvodného argumentu. Navyše rekonštrukcia R2 sa od rekonštrukcie R1 líši aj v tom, že pravdivost' premisy (P1) - t. j. výroku „Ak má liečivo $\mathrm{X}$ nežiaduce vedlajšie účinky, tak laboratórne testy $\mathrm{t}_{1}, \ldots, \mathrm{t}_{\mathrm{n}}$ odhalia, že X má nežiaduce účinky“ - môže byt' (prinajmenšom) otázna. Stav vecí môže byt' taký, že hoci liečivo X má nežiaduce vedlajšie účinky, laboratórne testy ich nedokážu odhalit'. V takom prípade by bol uvedený výrok nepravdivý. To by však znamenalo, že informačný obsah argumentu (RA2) - konjunkcia premís (P1) a (P2) - by nebol nepravdivý. Rekonštrukcia R2 by v takom prípade nezachovávala pravdivost' informačného obsahu pôvodného argumentu.

A ako je na tom rekonštrukcia R3 - teda prechod od (A) k (RA3) a prechod od (RA3) k (FR3)? Možno povedat', že R3 transformuje pôvodný argument (A) na komparatívny výrok, ktorý porovnáva východiskovú pravdepodobnost' záveru (bez zohl'adnenia negatívnej evidencie) s následnou pravdepodobnost'ou záveru podmienenou negatívnou evidenciou, ktorá zasa korešponduje s premisou pôvodného argumentu (A), pričom daný komparatívny výrok vyjadruje tézu, že následná pravdepodobnost' je vyššia ako východisková pravdepodobnost'. Treba mat' na pamäti, že rekonštrukcie (RA3) a (FR3) sú len skratkou za komplexnejší proces inferencie, vyjadrený Bayesovou teorémou a bayesiánskym kritériom potvrdenia. Jednotlivé prvky Bayesovej teorémy (BT) na pravej strane možno, obrazne povedané, chápat' ako premisy inferenčného procesu, pričom záverom tohto procesu je l'avá strana (BT). Napríklad, ako sme už v tretej časti povedali, $\operatorname{Pr}(\neg \mathrm{E} \mid \neg \mathrm{H})$ vyjadruje pravdepodobnost', že laboratórne testy budú negatívne (teda neukážu nežiaduce účinky liečiva $\mathrm{X}$ ) za predpokladu, že liečivo X je bezpečné (a teda nevyvoláva žiadne nežiaduce účinky). Keby hodnota tejto pravdepodobnosti bola rovná 1 , tak by sme dostali ekvivalentné tvrdenie, že ak liečivo X nemá žiadne nežiaduce účinky, tak neexistuje evidencia, že X má nežiaduce účinky. Tento výrok reprezentoval premisu argumentu (RA2) rekonštrukcie R2. Bayesiánska rekonštrukcia však pripúšt’a, že hodnota $\operatorname{Pr}(\neg \mathrm{E} \mid \neg \mathrm{H})$ je nižšia ako 1 , hoci sa k hodnote 1 blíži. Predpoklad, že $\operatorname{Pr}(\neg \mathrm{E} \mid \neg \mathrm{H})<1$ je $\mathrm{z}$ hl'adiska posúdenia jeho pravdivosti prijatel’nejší ako predpoklad, že $\operatorname{Pr}(\neg \mathrm{E} \mid \neg \mathrm{H})=1$, alebo že premisa „Ak má liečivo $\mathrm{X}$ nežiaduce vedlajšie účinky, tak laboratórne testy $\mathrm{t}_{1}, \ldots, \mathrm{t}_{\mathrm{n}}$ odhalia, že $\mathrm{X}$ má nežiaduce účinky“ argumentu (RA2) z predchádzajúcej rekonštrukcie je pravdivá. R3 
preto umožňuje ústretovejšie ohodnotenie rekonštruovaných premís prítomných $\mathrm{v}$ (BT) za pomoci pravdepodobnosti.

R3 je preto pomerne komplexnou rekonštrukciou, ktorej analýza predpokladá viacero čiastkových krokov. Samozrejme, R3 môže byt' najviac vzdialená tomu, s akými predpokladmi autor (A) pracoval, ked' formuloval daný argument. Na druhej strane argument (A) skratkovito reprodukuje výsledky farmakologického výskumu, pričom platí, že testovanie liečiv sa vykonáva prostredníctvom štatistických testov, kde pravdepodobnosti majú svoje miesto. $Z$ tohto dôvodu preto nemusí byt' dôležité, či autor argumentu (A) v skutočnosti pracoval alebo nepracoval s pravdepodobnost’ami. Rekonštrukcia R3 totiž môže adekvátne zachytávat' proces výskumu, o ktorom argument (A) vypovedá len v povrchnej podobe. Problémom R3 však môže byt' určenie jednotlivých hodnôt pravdepodobnostnej funkcie Pr v Bayesovej teoréme. Ak aj prijmeme predpoklad, že autor bayesiánskej rekonštrukcie alebo konkrétny tím výskumníkov pridelil jednotlivým prvkom (BT) konkrétne pravdepodobnostné hodnoty, prirodzeným dôsledkom tohto druhu rekonštrukcie je skutočnost', že odlišní aktéri môžu ten istý argument hodnotit' odlišne, ked'že stupne ich presvedčenia - vyjadrené v (BT) - sa môžu (výrazne) líšit'. Na druhej strane, R3 obsahuje ako svoju súčast' výroky, ktoré zachovávajú nededuktívny - v tomto prípade pravdepodobnostný - charakter vzt'ahu medzi premisou a záverom pôvodného argumentu (vyjadrený napríklad zložkou $\operatorname{Pr}(\neg \mathrm{E} \mid \neg \mathrm{H})$ ). A preto R3 je vernejšou rekonštrukciou nededuktívnej relácie argumentu (A) než rekonštrukcia R2.

Máme teda pred sebou tri odlišné (druhy) rekonštrukcie argumentu (A), z ktorých každá má svoje slabé i silné stránky (vo vzt’ahu k niektorým logickým, metodologickým a pragmatických vlastnostiam pôvodného argumentu). Prirodzene sa preto vynára otázka, ktorú z uvedených rekonštrukcií možno preferovat' (ak vôbec nejakú), respektíve na základe akého kritéria selekcie možno vybrat' vhodnú rekonštrukciu?

Ked'že uvedené rekonštrukcie sa opierajú o odlišné teoretické rámce, je pochopitel'né, že hladaný selekčný princíp nie je vhodné hladat' priamo v niektorom z teoretických rámcov (a to bez ohl'adu na to, či ide o logický systém klasickej predikátovej logiky prvého rádu alebo o transparentnú intenzionálnu logiku či bayesiánsku epistemológiu). Napriek tomu môžeme využit’ doterajšie výsledky našej analýzy a na základe silných stránok tej či onej rekonštrukcie môžeme sformulovat' tri potenciálne princípy selekcie:

(S1) Spomedzi rekonštrukcií $\mathrm{R}_{1}, \ldots, \mathrm{R}_{\mathrm{n}}$ pôvodného argumentu A vyber takú rekonštrukciu $\mathrm{R}_{\mathrm{i}}$, ktorá (v najväčšej miere) zachováva informačný obsah premís i druh inferenčnej relácie A! 
(S2) Spomedzi rekonštrukcií $\mathrm{R}_{1}, \ldots, \mathrm{R}_{\mathrm{n}}$ pôvodného argumentu A vyber takú rekonštrukciu $\mathrm{R}_{\mathrm{i}}$, ktorá reprezentuje alebo transformuje inferenčnú reláciu A na reláciu logického vyplývania!

(S3) Spomedzi rekonštrukcií $\mathrm{R}_{1}, \ldots, \mathrm{R}_{\mathrm{n}}$ pôvodného argumentu A vyber takú rekonštrukciu $R_{i}$, ktorá ( $v$ najväčšej miere) zachováva druh inferenčnej relácie A a maximalizuje pravdivost' (respektíve prijatel'nost') informačného obsahu premís A!

Prirodzene, princípy (S1) - (S3) nie sú jediné možné kritériá selekcie, no ich porovnanie s našimi troma rekonštrukciami $\mathrm{R} 1$ - R3 postačuje na formuláciu záveru našej analýzy. Venujme sa teraz jednotlivým porovnaniam.

Zdá sa, že ak by sme na naše tri rekonštrukcie použili princíp (S1), preferovanou by bola rekonštrukcia R1, pretože (ako jediná z troch rekonštrukcií) zachováva pôvodný informačný obsah a nemení ani druh pôvodnej inferenčnej relácie predmetného argumentu.

Na druhej strane, keby sa náš výber riadil princípom (S2), mali by sme dôvod preferovat' rekonštrukciu R2. Princíp (S2) by tak zodpovedal prístupu, ktorý sa na (pôvodne) nededuktívne argumenty pozerá ako na (potenciálne) entymematické argumenty, t. j. argumenty, ktoré majú (aspoň) jednu premisu zamlčanú, pričom zvyčajne ide o premisu, ktorej dodanie k pôvodnej množine premís zabezpečuje, že sa pôvodný argument transformuje na deduktívne platný argument. Problémom tohto prístupu vo všeobecnosti (a konkrétne aj v prípade rekonštrukcie R2) je fakt, že pridanie vhodnej premisy síce zabezpečí logickú platnost' argumentu, no pravdivost' dodanej premisy môže byt' (prinajmenšom) otázna.

Napokon ak by sme pri selekcii rekonštrukcií pracovali s princípom (S3), pravdepodobne by sme sa priklonili k rekonštrukcii R3. Ide totiž o rekonštrukciu, ktorá na jednej strane zachováva nededuktívny charakter inferenčnej relácie v argumente (A), no na druhej strane maximalizuje plauzibilnost' premisy pôvodného argumentu. Je prijatel'né tvrdit', že testy na odhalenie toxických účinkov daného liečiva síce nie sú spol'ahlivé na $100 \%$, no sú dostatočne spol'ahlivým indikátorom bezpečnosti či škodlivosti liekov.

Tri potenciálne princípy selekcie teda vyberajú tri odlišné rekonštrukcie. Prirodzene, tento stav nerieši problém selekcie optimálnej rekonštrukcie. Na mieste je preto otázka, či existujú nejaké d’alšie (rozumné) dôvody na to, aby sme sa riadili skôr jedným než ostatnými dvoma princípmi?

Domnievam sa, že riešenie problému selekcie je naporúdzi, ak si uvedomíme, že sama rekonštrukcia, analýza a hodnotenie argumentov môže vo vedeckom, expertnom i bežnom diskurze plnit' rôznorodé ciele. Prirodzene, ak je ciel'om rekonštrukcie daného argumentu priblížit' sa čo najvernejšie k zachyteniu predpokladov a inferenčného procesu autora argumentu, tak adekvátnou vol'bou je selekcia jednej spomedzi potenciálnych rekonštrukcií v zmysle princípu (S1). No ak je ciel’om demonštrácia 
okolností, za ktorých je predmetný argument logicky platný, preferenčným princípom bude (S2). A ak modelujeme usudzovanie aktéra, ktorý okrem presvedčení disponuje stupňami presvedčenia, tak vhodným môže byt' práve použitie princípu (S3). Rôznym ciel'om tak môžu vyhovovat' odlišné selekčné princípy.

Princípy selekcie (S1) - (S3) sme formulovali ako kategorické príkazy. Ukazuje sa však, že ich zmysluplné a adekvátne použitie je podmienené kontextom použitia príslušnej rekonštrukcie a ciel'om, ktorý v danom kontexte rekonštrukcia sleduje. Vo všeobecnosti je preto vhodné preformulovat' jednotlivé selekčné princípy do podoby:

(SP) Ak sleduješ ciel' $C_{i}$, použi princíp $S_{j}$ !

Hypotetický imperatív (SP) tak vyjadruje skutočnost', že rôznym ciel’om, ktoré sú v pozadí procesu rekonštrukcie, analýzy a hodnotenia argumentov, môžu vyhovovat' odlišné princípy výberu optimálnej rekonštrukcie. Náš návrh selekčných princípov je, samozrejme, skôr ilustračný a v každom prípade pripúšt’a doplnenie či modifikáciu. Podobne aj databáza potenciálnych ciel’ov využitia rekonštrukcie, analýzy a hodnotenia argumentov je príliš bohatá na to, aby sme sa pokúsili o vyčerpávajúce vymenovanie jej prvkov. Naša analýza niektorých aspektov rekonštrukcie argumentov však ukazuje, že výber jednej spomedzi viacerých možných rekonštrukcií nie je homogénny proces, ale ide o komplexnú činnost', ktorá prihliada na rôznorodé, kontextom rekonštrukcie podmienené ciele, ktorým môže vyhovovat' v jednom prípade jedna, v inom prípade iná rekonštrukcia. Výber vhodnej rekonštrukcie tak nie je determinovaný logickými, metodologickými či pragmatickými vlastnost’ami, ktoré reprezentuje ten alebo onen teoretický rámec, ale prichádza takpovediac ,Zvonka“ - z širšieho komunikačného a kognitívneho kontextu, v ktorom príslušný argument plní určitú funkciu.

\section{Literatúra}

BIELIK, L. (2019a): Metodologické aspekty vedy. Univerzita Komenského v Bratislave.

BIELIK, L. (2019b): Druhy nezhody a ich (semi)formálna rekonštrukcia. Filozofia, 74 (9), 690 704. DOI: https://doi.org/10.31577/filozofia.2019.74.9.1

BONEVAC, D. (1999): Simple Logic. New York - Oxford: Oxford University Press.

CARNAP, R. (1962/1950): The Logical Foundations of Probability. 2nd ed. Chicago: The University of Chicago Press.

COPI, M. I., COHEN, C., MCMAHON, K. (2014): Introduction to Logic. 14th ed. Pearson Education Limited.

HAHN, U., OAKSFORD, M. (2006): A Bayesian Approach to Informal Argument Fallacies. Synthese 152,207 - 236. DOI: https://doi.org/10.1007/s11229-005-5233-2

HALAS, J. (2019): Abstrakcia, idealizácia a používanie argumentov. Filozofia,74 (9), 705 -720. DOI: https://doi.org/10.31577/filozofia.2019.74.9.2 
HALAS, J. (2016): Abstrakcia a idealizácia. Bratislava: Univerzita Komenského v Bratislave.

HOWSON, C., URBACH, P. (1993): Scientific Reasoning. The Bayesian Approach. 2nd. ed. Chicago - La Salle: Open Court.

JONES, M. R. (2005): Idealization and Abstraction: A Framework. In: Jones, M. R. - Cartwright, N. (eds.): Idealization XII: Correcting the Model. Amsterdam: Rodopi, 173 - 217.

KOLMOGOROV, A. N. (1950): Foundations of the Theory of Probability. New York: Chelsea Publishing Company.

KYBURG, H. E., TENG, CH. M. (2001): Uncertain Inference. Cambridge: Cambridge University Press.

OAKSFORD, M., HAHN, U. (2004): A Bayesian Approach to the Argument from Ignorance. Canadian Journal of Experimental Psychology, 58 (2), 75 - 85. DOI: https://doi.org/10.1037/h0085798

PICHA, M. (2014): Kritické myšlení a rekonstrukce argumentu. Brno: Masarykova univerzita.

ROEPER, P., LEBLANC, H. (1999): Probability Theory and Probability Semantics. Toronto - Buffalo - London: University of Toronto Press.

STEPHENS, CH. (2011): A Bayesian Approach to Absent Evidence Reasoning. Informal Logic, 31 (1), 56 - 65. DOI: https://doi.org/10.22329/il.v31i1.2967

VAN EEMEREN, F. H., GARSSEN, B., KRABBE, E. C. W., HENKEMANS, A. F. S., VERHEIJ, B., WAGEMANS, J. H. M. (2014): Handbook of Argumentation Theory. Dordrecht - Heidelberg - New York - London: Springer.

WALTON, D., REED, C., MACAGNO, F. (2008): Argumentation Schemes. Cambridge: Cambridge University Press.

WALTON, D. (1996): Arguments from Ignorance. Pennsylvania: The Pennsylvania State University Press. WALTON, D. (1992): Nonfallacious Arguments from Ignorance. American Philosophical Quar terly 29, $381-387$.

ZOUHAR, M., BIELIK, L., KOSTEREC, M. (2017): Metóda: metodologické a formálne aspekty Bratislava: Univerzita Komenského v Bratislave.

Práca na tomto článku bola podporená projektom č. APVV-17-0057 Analýza, rekonštrukcia a hodnotenie argumentov.

Lukáš Bielik

Katedra logiky a metodológie vied

Filozofická fakulta UK v Bratislave

Gondova 281499 Bratislava

Slovenská republika

e-mail: lukas.bielik@uniba.sk

ORCID ID: https://orcid.org/0000-0002-3918-8392 